\title{
Intensitas Aktiva Tetap, Kompensasi Eksekutif, Kepemilikan Institusional dan Tax Avoidance
}

\author{
Luh Pringgita Tami Sarasmita ${ }^{1}$ \\ Fakultas Ekonomi dan Bisnis \\ Universitas Udayana, Indonesia
}

\author{
Ni Made Dwi Ratnadi² \\ Fakultas Ekonomi dan Bisnis \\ Universitas Udayana, Indonesia
}

\begin{abstract}
Surel : gitasarasmita@gmail.com
ABSTRAK

Penelitian ini bertujuan untuk memperoleh bukti empiris mengenai pengaruh intensitas aktiva tetap, kompensasi eksekutif, dan kepemilikan institusional pada tax avoidance di Perusahaan Sektor Manufaktur yang terdapat di BEI periode 2016-2019. Sampel ditentukan menggunakan metode nonprobability sampling dengan teknik purposive sampling, diperoleh sebanyak 55 perusahaan dengan tahun pengamatan selama 4 tahun sehingga diperoleh data sebanyak 220 amatan. Teknik analisis data menggunakan uji Regresi Linier Berganda. Hasil penelitian ini menunjukan bahwa intensitas aktiva tetap dan kepemilikan institusional berpengaruh negatif pada tax avoidance. Hal ini berarti semakin tinggi intensitas aktiva tetap perusahaan dan semakin besar kepemilikan institusional perusahaan menyebabkan rendahnya tingkat tax avoidance. Kompensasi eksekutif berpengaruh positif pada tax avoidance. Hal ini berarti bahwa semakin tinggi kompensasi yang diberikan kepada eksekutif semakin tinggi tingkat tax avoidance.
\end{abstract}

Kata Kunci: Intensitas Aktiva Tetap; Kompensasi Eksekutif; Kepemilikan Institusional; Tax Avoidance.

\section{Fixed Asset Intensity, Executive Compensation, Institutional Ownership and Tax Avoidance}

\begin{abstract}
This study aims to obtain empirical evidence regardingthe effect of fixed asset intensity, excecutive compensation, and institusional ownership on tax avoidance in the Mining Sector Manufactur contained on the Stock Exchange in the 2016-2019. The sample was determained using the nonprobability sampling method with a purposive sampling technique, obtained as many as 55 companies with 4 of observation in order to obtain 220 data observations. Data analysis techniques using the Multiple Liniear Regression test. The sampling method used is purposive sampling. Data analysis techniques using the Multiple Linear Regression test. The results of this study indicate that the intensity of fixed assets and institutional ownership has a negative effect on tax avoidance. This means that the higher the intensity of the company's fixed assets and the greater the company's institutional ownership causes the lower level of tax avoidance. Executive compensation has a positive effect on tax avoidance. This means that the higher the compensation given to the executive, the higher the level of tax avoidance.
\end{abstract}

Keywords: Fixed Asset Intensity; Excecutive Compensation; Institusional Ownership; Tax Avoidance.

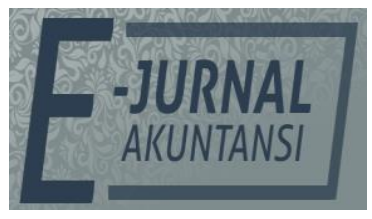

e-ISSN 2302-8556

Vol. 31 No. 10

Denpasar, Oktober 2021

Hal. 2442-2452

DOI:

10.24843/EJA.2021.v31.i10.p03

PENGUTIPAN:

Sarasmita, L.P.T., \& Ratnadi,

N.M.D. (2021). Intensitas

Aktiva Tetap, Kompensasi

Eksekutif, Kepemilikan Institusional dan Tax

Avoidance. E-Jurnal Akuntansi, 31(10), 2442-2452

RIWAYAT ARTIKEL: Artikel Masuk: 4 Oktober 2020 Artikel Diterima: 27 Oktober 2021

Artikel dapat diakses : https://ojs.unud.ac.id/index.php/Akuntansi/index 


\section{PENDAHULUAN}

Pajak adalah sumber pendapatan terbesar negara yang digunakan untuk membiayai pengeluaran negara bagi pemerintah. Pajak dapat menjadi beban masyarakat karena mengurangi pendapatan mereka. Hal ini mengakibatkan wajib pajak untuk melakukan minimalisasi pembayaran pajak yaitu salah satunya dengan menghindari pajak atau tax avoidance. Tax avoidance adalah upaya menghindari pajak yang tidak melanggar aturan perpajakan dan aman bagi wajib pajak. Penghindaran pajak merupakan persoalan atau permasalahan yang rumit tetapi unik karena disatu sisi diperbolehkan, tetapi tidak diinginkan (Maharani \& Suardana, 2014). Self assessment system adalah sistem pemungutan pajak yang dianut di Indonesia yang memberikan kewenangan kepada wajib pajaknya untuk menghitung serta melaporkan sendiri besaran pajak terutangnya. Akan tetapi, penerapan self assessment system dalam kenyataannya rentan terhadap adanya penyelewengan dan pelanggaran yang salah satunya adalah penghindaran pajak (Mulyani et al., 2014).

Salah satu fenomena tax avoidance ditunjukkan dari penerbitan Surat Ketetapan Pajak Kurang Bayar (SKPKB) oleh Direktorat Jenderal Pajak (DJP). Hal ini mengartikan perusahaan yang menerima SKPKB diindikasi melakukan tax avoidance karena memiliki tambahan jumlah pajak kurang bayar (Resmi, 2012:34). Perusahaan manufaktur yang menerima SKPKB dilihat pada Tabel 1.

Tabel 1. Perusahaan Manufaktur yang Menerima Surat Ketetapan Pajak Kurang Bayar (SKPKB) 2019

\begin{tabular}{llc}
\hline No & Perusahaan & $\begin{array}{c}\text { Kurang Bayar } \\
\text { (dalam rupiah) }\end{array}$ \\
\hline 1 & PT Mandom Indonesia Tbk & $18.486 .579 .360,00$ \\
2 & PT Wijaya Karya Beton Tbk. & $5.216 .978 .510,00$ \\
3 & PT Ekadharma InternationalTbk. & $3.082 .273 .129,00$ \\
4 & PT Lotte Chemical Titan Tbk. & $4.000 .000 .000,00$ \\
\hline
\end{tabular}

Sumber: Annual Report Perusahaan Manufaktur, 2020

Tabel 1, menggambarkan SKPKB yang diterima dari beberapa perusahaan manufaktur pada tahun 2019. Perusahaan tersebut yaitu PT Mandom Indonesia Tbk., PT Wijaya Karya Beton Tbk., PT Ekadharma International Tbk., dan PT Lotte Chemical Titan Tbk. Perusahaan manufaktur yang menerima SKPKB tersebut diindikasi tidak jujur dalam melaporkan jumlah pajaknya namun hal ini bertentangan dengan harapan pemerintah dalam sistem pemungutan pajak yaitu self assessment system (Dwiyanti \& Jati, 2019). Kasus penghindaran pajak merupakan masalah serius di Indonesia.

Tax avoidance dipengaruhi banyak faktor. Dharma \& Ardiana (2016) meneliti praktik tax avoidance diantaranya leverage, intensitas aset tetap, ukuran perusahaan, dan koneksi politik. Dewi \& Sari (2015) meneliti faktor lain yang memengaruhi praktik tax avoidance yakni financial distress, karakteristik eksekutif, dan kompensasi eksekutif. Mahulae et al., (2016) meneliti faktor-faktor yang memengaruhi diterapkannya praktik tax avoidance adalah kepemilikian institusional, kepemilikan manajerial, dan komite audit.

Penelitian ini mengkombinasikan variabel intensitas aktiva tetap, kompensasi eksekutif, dan kepemilikan institusional. Variabel intensitas aktiva 
tetap dipilih karena dapat memengaruhi pembayaran pajak suatu perusahaan yang dapat dilihat dari banyaknya perusahaan melakukan investasi terhadap aktiva tetap perusahaan. Kompensasi eksekutif dipilih karena menjadi salah satu faktor penting yang dapat memengaruhi keberhasilan suatu bisnis dan sebagai salah satu upaya efisiensi pembayaran pajak. Kepemilikan institusional digunakan sebagai variabel karena kepemilikan institusional yang terdapat di suatu perusahaan dapat memengaruhi kebijakan dalam perusahaan tersebut.

Teori keagenan menurut Eisenhardt (1989) menggunakan tiga asumsi sifat dasar manusia diantaranya adalah manusia umumnya mementingkan diri sendiri, manusia memiliki daya pikir terbatas mengenai persepsi masa mendatang, dan manusia selalu menghindari risiko. Dapat dilihat dari tiga asumsi sifat dasar manusia tersebut bahwa munculnya masalah keagenan dipicu adanya sifat dasar manusia. Maka dari itu teori keagenan ini memungkinkan adanya asimetri informasi antara prinsipal dan agen. Jensen \& Meckling (1976) juga mengemukakan teori ini yang menjelaskan hubungan keagenan sebagai kontrak antara satu orang atau lebih untuk melakukan sejumlah jasa dan memberikan wewenang dalam pengambilan keputusan kepada pihak lain. Konflik keagenan muncul apabila tujuan yang ingin dicapai oleh manajer perusahaan tidak sejalan dengan kepentingan pemegang saham (Nariastiti \& Ratnadi, 2014). Prinsipal harus selalu mengawasi tindakan yang dilakukan oleh manajemen. Tujuan dilakukan hal itu agar setiap tindakan atau keputusan yang diambil sesuai tujuan perusahaan (Lestari \& Dwija Putri, 2017).

Tindakan tax avoidance yang dilakukan perusahaan dapat diukur dengan berbagai proksi, antara lain adalah Cash Effective Tax Ratio (CETR), Effective Tax Ratio (ETR), dan Book Tax Differencec (BTD). CETR merupakan kas yang dikeluarkan perusahaan yang digunakan untuk membayar pajak terhadap laba sebelum pajak yang dihasilkan perusahaan tersebut (Budiman \& Setiyono, 2012). Menurut Dyreng et al. (2010) pengukuran tax avoidance yang baik untuk digunakan dalam memprediksi tindakan tersebut adalah CETR. Nilai dari CETR tersebut tidak berpengaruh pada perubahan estimasi seperti adanya perlindungan pajak. Tingginya tingkat presentase CETR mengindikasi tingkat tax avoidance rendah dan sebaliknya.

Seiring berkembangnya perusahaan, segala cara akan dilakukan oleh para manajer untuk memperbesar laba perusahaan. Ketika perusahaan memutuskan untuk meningkatkan melakukan investasi dalam bentuk aktiva tetap, maka beban depresiasi yang diakibatkan dari aktiva tetap meningkat pula. Keadaan ini tentu mengakibatkan laba perusahaan berkurang dan pajak yang dibayar perusahaan juga menjadi berkurang (Jama' \& Harnovinsah, 2018). Berdasarkan uraian, hipotesis yang dapat dirumuskan dalam penelitian ini adalah sebagai berikut.

$\mathrm{H}_{1}$ : Intensitas aktiva tetap berpengaruh negatif padatax avoidance.

Kompensasi di Indonesia rata-rata meliputi gaji atau honorarium, tunjangan, dan bonus (Nugraha \& Mulyani, 2019). Pemberian kompensasi terhadap eksekutif yang tinggi merupakan suatu cara dalam melakukan minimalisasi pajak perusahaan. Sebagai pemimpin operasional perusahaan, kebijakan tax avoidance dapat dibuat oleh eksekutif apabila dalam situasi itu juga eksekutif diuntungkan atas kebijakan yang dibuatnya. Berdasarkan uraian, maka 
hipotesis yang dapat dirumuskan berdasarkan penjelasan tersebut adalah sebagai berikut.

$\mathrm{H}_{2}$ : Kompensasi eksekutif berpengaruh positif pada tax avoidance.

Kepemilikan institusional adalah merupakan saham yang sebagian besar dimiliki pihak institusi lain atau lembaga lainnya. Lembaga tersebut seperti perusahaan asuransi, bank, perusahaan investasi, dan kepemilikan institusi lain. Adanya kepemilikan institusional tentunya menyebabkan pengawasan atas perusahaan yang optimal karena investor institusional lebih aktif dalam mengawasi perusahaan (Praditasari \& Setiawan, 2017). Pihak institusional dapat memantau manajemen perusahaan terkait ketaatan peraturan perpajakan. Ini diakibatkan adanya tanggung jawab perusahaan kepada negara dalam hal membayar pajak yang nantinya akan memaksimalkan kesejahteraan pemegang saham. Berdasarkan uraian, maka hipotesis yang dapat dirumuskan sebagai berikut.

$\mathrm{H}_{3}$ : Kepemilikan institusional berpengaruh negatif pada tax avoidance.

\section{METODE PENELITIAN}

Penelitian tentang tax avoidance ini menggunakan pendekatan kuantitatif yang berbentuk asosiatif. Bursa Efek Indonesia (BEI) merupakan tempat dilakukannya penelitian ini. Ruang lingkup penelitian ini adalah perusahaan sektor manufaktur yang terdaftar di BEI. Objek penelitian dalam penelitian ini adalah tax avoidance yang dijelaskan oleh intensitas aktiva tetap, kompensasi eksekutif, dan kepemilikan institusional yang diproksikan melalui rasio-rasio keuangan perusahaan manufaktur yang terdapat di BEI periode 2016-2019. Variabel yang digunakan dalam penelitian ini adalah intensitas aktiva tetap $\left(X_{1}\right)$, kompensasi eksekutif $\left(\mathrm{X}_{2}\right)$, kepemilikan institusional $\left(\mathrm{X}_{3}\right)$, dan tax avoidance $(\mathrm{Y})$.

Jenis data dalam penelitian ini adalah data kuantitatif yaitu pembayaran pajak perusahaan, laba sebelum pajak perusahaan, jumlah kompensasi direksi dan komisaris, total kepemilikan saham oleh pihak institusi, dan jumlah saham beredar yang terdapat di laporan tahunan perusahaan. Penggunaan CETR juga dilakukan oleh peneliti seperti Minick \& Noga (2010). CETR dihitung dengan rumus dari Hanlon \& Heitzman (2010), yaitu sebagai berikut.

Tax Avoidance $($ CETR $)=\frac{\text { Cash } T \text { axPaidi, },}{\text { PretaxIncomei, },} \times 100 \%$

Keterangan :

Cash Tax Paid $i, t=$ Pembayaran pajak badan oleh perusahaan i pada laporan arus kas perusahaan periode $t$

Pretax Income $i, t \quad=$ Laba sebelum pajak perusahaan i pada periode $\mathrm{t}$

Reminda (2017) dalam Sinaga \& Suardikha (2019) mengatakan intensitas aktiva tetap merupakan rasio antara fiex asset terhadap total asset. Intensitas aktiva tetap dihitung dengan cara sebagai berikut.

Intensitas Aktiva Tetap $=\frac{\text { Total Aset Tetap }}{\text { Total Aset }} \times 100 \%$

Dalam penelitian ini pengukuran kompensasi eksekutif dilihat dari jumlah keseluruhan kompensasi yang diberikan kepada dewan komisaris dan direksi berupa gaji, tunjangan atau imbalan kerja lainnya yang diterima eksekutif selama satu tahun. Persamaan yang digunakan untuk menghitung kompensasi eksekutif yaitu sebagai berikut. 
Kompensasi Eksekutif = Jumlah Kompensasi Direksi \& Komisaris

\section{HASIL DAN PEMBAHASAN}

Statistik deskriptif dalam penelitian ini memberikan gambaran mengenai data yang tersaji seperti nilai minimum, nilai maksimum, nilai rata-rata (mean) dan standar deviasi.

Tabel 2. Hasil Uji Statistik Deskriptif

\begin{tabular}{llrrrr}
\hline & $\mathrm{N}$ & Minimum & Maximum & \multicolumn{1}{c}{ Mean } & \multicolumn{1}{c}{ Std. Deviation } \\
\hline Intensitas Aktiva Tetap & 220 & 0,030 & 1,112 & 0,458 & 0,171 \\
Kompensasi Eksekutif & 220 & 7,000 & 995,000 & 65041,181 & 1,662 \\
Kepemilikan Institusional & 220 & 0,050 & 0,998 & 0,697 & 0,180 \\
Tax Avoidance & 220 & $-5,948$ & 4,367 & 0,361 & 0,634 \\
\hline
\end{tabular}

Sumber: Data Penelitian, 2020

Tabel 2, dapat dijelaskan yaitu data variabel intensitas aktiva tetap berjumlah 220, nilai minimum sebesar 0,030 oleh PT. Alakasa Industrindo Tbk (ALKA) pada tahun 2019 dan nilai maksimum sebesar 1,112 oleh PT. Jembo Cable Company Tbk (JECC) pada tahun 2019. Intensitas aktiva tetap memiliki rata-rata sebesar 0,458 dan standar deviasi intensitas aktiva tetap adalah 0,171 . Ini berarti adapenyimpangan data pada nilai rata-ratanya yakni sebesar 0,458 dan nilai penyimpangan data intensitas aktiva tetap tersebut lebih kecil dari nilai rataratanya, maka sebaran data intensitas aktiva tetap cukup dekat.

Data variabel kompensasi eksekutif berjumlah 220 dengan nilai minimum sebesar 7,000 oleh PT. Indah Klat Pulp \& Paper Tbk (INKP) pada tahun 2018 dan nilai maksimum sebesar 995,000 oleh PT. Astra International Tbk (ASII) tahun 2016. Variabel kompensasi eksekutif memiliki rata-rata sebesar 65041,181 dan standar deviasi kompensasi eksekutif sebesar 1,662. Ini berarti ada penyimpangan data pada nilai rata-ratanya sebesar 1,662 dan nilai penyimpangan data kompensasi eksekutif lebih kecil dari nilai rata-ratanya, maka sebaran data kompensasi eksekutif cukup dekat.

Data variabel kepemilikan institusional berjumlah 220. Nilai minimum 0,050 dimiliki perusahaan PT. Wismilak Inti Makmur Tbk (WMII) pada tahun 2018 dan nilai maksimum yaitu 0,998 dimiliki perusahaan PT. Mark Dynamics Indonesia Tbk (MARK) tahun 2016. Variabel kepemilikan institusional memiliki rata-rata sebesar 0,697. Nilai standar deviasi kepemilikan institusional adalah 0,180 . Artinya ada penyimpangan data pada nilai rata-ratanya sebesar 0,180 dan nilai penyimpangan data kepemilikan institusional tersebut lebih kecil dari nilai rataratanya, maka sebaran data kepemilikan institusional cukup dekat.

Data tax avoidance berjumlah 220 dengan nilai minimum sebesar $-5,948$ oleh PT. Mulia Industrindo Tbk (MLIA) tahun 2016 dan nilai maksimum sebesar 4,367 oleh PT. Alakasa Indonesia Industrindo Tbk (ALKA) pada tahun 2016. Tax avoidance memiliki mean sebesar 0,361 dengan nilai standar deviasi tax avoidance sebesar 0,634 . Artinya ada penyimpangan data pada nilai rata-ratanya sebesar 0,634 dan nilai penyimpangan data tax avoidance tersebut lebih besar dari nilai rataratanya, maka sebaran data tax avoidance cukup jauh.

Analisis regresi linier berganda adalah metode analisis yang dapat digunakan untuk mengetahui hubungan antara dua variabel atau lebih. Dalam penelitian ini dilakukan untuk mengetahui adanya pengaruh dan arah pengaruh 
variabel bebas terhadap variabel terikat, atau apakah memiliki pengaruh positif atau negatif. Model regresi terlebih dahulu harus diuji untuk memenuhi asumsi klasik. Jikadalam uji tersebut ada satu syarat yang tidak terpenuhi, maka hasil analisis regresi tidak dapat dikatakan bersifat Best Linier Unbias Estimator (BLUE). Berikut akan dijelaskan tentang uji asumsi klasik dalam penelitian ini.

Uji normalitas dilakukan dengan tujuan mengetahui model regresi yang dibuat berdistribusi normal atau tidak. Model regresi yang baik adalah memiliki nilai residual yang berdistribusi normal. Pengujian normalitas data dilakukan dengan menggunakan Kolmogorov-Smirnov (K-S).

Tabel 3. Uji Normalitas

\begin{tabular}{llr}
\hline & & Unstandardized Residual \\
\hline N & & 220 \\
& Mean & 0,002 \\
Most Extreme Differences & Std. Deviation & 0,884 \\
& Absolute & 0,087 \\
& Positive & 0,087 \\
Kolmogorov-Smirnov Z & Negative & $-0,063$ \\
Asymp. Sig. (2-tailed) & & 1,285 \\
\hline Sumbeters & & 0,073 \\
\hline
\end{tabular}

Sumber: Data Penelitian, 2020

Pada Tabel 3, dapat dilihat bahwa nilai Kolmogorov-Smirnov sebesar 1,285 dan nilai signifikansi Asymp. Sig. (2-tailed) adalah 0,073. Nilai dari signifikansi uji Kolmogorov-Smirnov lebih dari 0,05 maka model regresi tersebut berdistribusi normal. Uji multikoliniertitas dilakukan dengan tujuan menguji model regresi yang digunakan apakah ada korelasi antar variabel bebas (independen) atau tidak. Apabila tidak terjadi korelasi diantara variabel bebasnya, maka model regresi tersebut terbebas dari multikoliniearitas. Hal tersebut dapat diketahui dengan melihat nilai tolerance dan nilai VIF. Jika nilai tolerance lebih dari 0,10 dan Variance Inflation Faktor (VIF) kurang dari 10, maka model regresi tersebut terbebas dari multikoliniearitas. Apabila sebaliknya, maka terjadi multikolinearitas. Hasil pengujian multikolinearitas dapat dilihat pada Tabel 4 .

Tabel 4. Uji Multikolinieritas

\begin{tabular}{lcc}
\hline & \multicolumn{2}{c}{ Collinearity Statistics } \\
\cline { 2 - 3 } (Constant) & Tolerance & VIF \\
Intensitas Aktiva Tetap & & \\
Kompensasi Eksekutif & 0,998 & 1,002 \\
Kepemilikan Institusional & 0,965 & 1,036 \\
\hline
\end{tabular}

Sumber: Data Penelitian, 2020

Berdasarkan Tabel 4, menunjukkan bahwa nilai tolerance dari variabel bebas yaitu intensitas aktiva tetap, kompensasi eksekutif, dan kepemilikan institusional lebih dari 0,10 dan VIF dari variabel-variabel tersebut kurang dari 10. Hal ini menunjukkan bahwa model regresi tersebut terbebas dari multikolinieritas

Untuk mengetahui apakah dalam model regresi terdapat ketidaksamaan varians dari residual satu pengamatan ke pengamatan lainnya maka dilakukan uji heteroskedastisitas. Apabila nilai signifikansi dari seluruh variabel bebas yang digunakan lebih besar dari 0,05, maka model regresi tidak mengandung gejala heteroskedastisitas. Uji heteroskedastisitas penelitian ini dijelaskan pada Tabel 5. 
Tabel 5. Uji Heteroskedastisitas

\begin{tabular}{lcc}
\hline & $\mathrm{t}$ & Sig. \\
\hline (Constant) & 16,842 & 0,000 \\
Intensitas Aktiva Tetap & $-0,141$ & 0,888 \\
Kompensasi Eksekutif & 0,700 & 0,485 \\
Kepemilikan Institusional & $-0,339$ & 0,735 \\
\hline
\end{tabular}

Sumber: Data Penelitian, 2020

Berdasarkan Tabel 5, dapat dilihat bahwa nilai signifikansidari variabel bebas yaitu intensitas aktiva tetap, kompensasi eksekutif, dan kepemilikan institusional masing-masing lebih besar dari 0,05. Hal ini menunjukkan bahwa model regresi tersebut terbebas dari gejala heteroskedastisitas.

Uji autokorelasi dilakukan untuk mengetahui adanya korelasi data dari tahun $\mathrm{t}$ dengan tahun sebelumnya. Model regresi yang baik adalah model regresi yang bebas dari autokolerasi dengan melihat nilai Durbin-Watson (dw). Berdasarkan hasil uji autokorelasi pada Tabel 6, nilai dari Durbin-Watson (dw) tersebut sebesar 1,802 dan jumlah variabel independen sebanyak $3(\mathrm{k}=3)$, maka diperoleh nilai $\mathrm{dl}=1,760 \mathrm{dan} \mathrm{du}=1,797$, sehingga 4-dl= 2,240 dan 4-du=2,203. Hasil uji autokorelasinya adalah $\mathrm{du}<\mathrm{d}<4$-du yaitu 1,797 $<1,802<2,203$, maka dapat disimpulkan bahwa data tersebut tidak terdapat autokorelasi.

Berdasarkan uraian, model regresi tersebut sudah memenuhi uji asumsi klasik dan berikut ini akan dijelaskan mengenai analisis regresi berganda yang dilakukan dalam penelitian ini. Analisis regresi linier berganda pada penelitian ini ditunjukkan pada Tabel 6 .

Tabel 6. Analisis Regresi Linier Berganda

\begin{tabular}{|c|c|c|c|c|c|}
\hline & \multicolumn{2}{|c|}{$\begin{array}{l}\text { Unstandardized } \\
\text { Coefficients }\end{array}$} & \multirow{2}{*}{$\begin{array}{c}\begin{array}{c}\text { Standardized } \\
\text { Coefficients }\end{array} \\
\text { Beta }\end{array}$} & \multirow[b]{2}{*}{$\mathrm{t}$} & \multirow[b]{2}{*}{ Sig. } \\
\hline & $\mathrm{B}$ & Std. Error & & & \\
\hline (Constant) & $-0,069$ & 0,068 & & $-1,010$ & 0,313 \\
\hline Intensitas Aktiva Tetap & $-0,318$ & 0,067 & $-0,294$ & $-4,743$ & 0,000 \\
\hline Kompensasi Eksekutif & 0,173 & 0,068 & 0,161 & 2,548 & 0,012 \\
\hline Kepemilikan Institusional & $-0,215$ & 0,067 & $-0,201$ & $-3,194$ & 0,002 \\
\hline$R$ Square & $: 0,172$ & & & & \\
\hline Adjusted R Square & $: 0,160$ & & & & \\
\hline F Statistik & $: 14,944$ & & & & \\
\hline Signifikansi & $: 0,000$ & & & & \\
\hline
\end{tabular}

Sumber: Data Penelitian, 2020

Berdasarkan Tabel 6, diperoleh suatu persamaan regresi sebagai berikut.

$$
\mathrm{Y}=-0,069-0,318 \mathrm{X}_{1}+0,173 \mathrm{X}_{2}-0,215 \mathrm{X}_{3}
$$

Interpretasi dari persamaan regresi adalah Nilai konstanta (a) -0,069 menunjukkan bahwa apabila intensitas aktiva tetap $\left(X_{1}\right)$, kompensasi eksekutif $\left(\mathrm{X}_{2}\right)$, dan kepemilikan institusional $\left(\mathrm{X}_{3}\right)$ sama dengan nol, maka nilai CETR (Y) sebesar $-0,069$. Nilai koefisien dari $\beta_{1}$ yaitu $-0,318$ artinya apabila nilai intensitas aktiva tetap $\left(X_{1}\right)$ naik 1 persen, maka nilai CETR $(Y)$ akan turun sebesar 31,8 persen. Nilai koefisien $\beta_{2}$ yaitu 0,173 artinya jika nilai kompensasi eksekutif $\left(X_{2}\right)$ naik 1 persen, maka nilai CETR (Y) akan naik 17,3 persen. Nilai koefisien $\beta_{3}$ yaitu-0,215 artinya jika nilai kepemilikan institusional $\left(\mathrm{X}_{3}\right)$ naik 1 persen, maka nilai CETR $(\mathrm{Y})$ akan turun 21,5 persen. 
Uji koefisien determinasi $\left(\mathrm{R}^{2}\right)$ dilakukan untuk mengukur seberapa jauh kemampuan variansi variabel independen dalam menerangkan variansi variabel dependen. Untuk mengetahui seberapa besar variabel independen dapat memengaruhi variabel dependen, maka dapat dilihat dari nilai Adjusted $R$ Square. Nilai koefisien determinasi adalah antara nol dan satu. Pada Tabel 6, nilai Adjusted $R$ Square adalah 0,160. Hal tersebut menjelaskan bahwa tax avoidance dapat dijelaskan oleh variabel intensitas aktiva tetap, kompensasi eksekutif, dan kepemilikan institusional sebesar 16 persen, sedangkan sisanya sebesar 84 persen dijelaskan oleh variabel lain di luar model.

Uji $\mathrm{F}$ bertujuan untuk menilai kelayakan model dalam penelitian ini dan mengetahui apakah semua variabel independen dalam model regresi mempunyai pengaruh terhadap variabel dependen. Untuk mengetahui uji $\mathrm{F}$ ini dengan melihat nilai signifikansi dari model regresi. Dikatakan lolos uji $\mathrm{F}$ jika nilai signifikansi kurang dari 0,05, maka model regresi layak dijadikan sebagai penelitian. Berdasarkan Tabel 6, menunjukkan nilai Sig. pada model sebesar 0,000 yaitu lebih kecil dari a sebesar 0,05, maka model penelitian layak digunakan sebagai alat analisis untuk menguji pengaruh variabel bebas terhadap variabel terikat. Hal ini berarti variabel intensitas aktiva tetap, kompensasi eksekutif, dan kepemilikan institusional berpengaruh terhadap variabel terikatnya yaitu tax avoidance.

Hipotesis pertama yang dirumuskan dalam penelitian ini yaitu intensitas aktiva tetap berpengaruh negatif pada tax avoidance. Pada Tabel 6, menunjukkan bahwa nilai signifikansi uji $\mathrm{t}$ untuk variabel intensitas aktiva tetap pada tax avoidance yaitu 0,000 lebih kecil dari a sebesar 0,05 dengan koefisien regresi bernilai negatif 0,318. Artinya hipotesis pertama yang dirumuskan penelitian ini dapat dinyatakan diterima. Hipotesis kedua penelitian ini yaitu kompensasi eksekutif berpengaruh positif pada tax avoidance. Tabel 6, menunjukkan nilai signifikansi uji t untuk variabel kompensasi eksekutif pada tax avoidance sebesar 0,012 lebih kecil dari a sebesar 0,05 dengan koefisien regresi bernilai positif 0,173 . Artinya hipotesis kedua yang dirumuskan penelitian ini dinyatakan diterima. Hipotesis ketiga yang dirumuskan dalam penelitian ini yaitu kepemilikan institusional berpengaruh negatif pada tax avoidance. Pada Tabel 6, menunjukkan bahwa nilai signifikansi uji $t$ untuk variabel kepemilikan institusional pada tax avoidance adalah 0,002 lebih kecil dari a sebesar 0,05 dengan koefisien regresi bernilai negativesebesar 0,215 . Ini berarti hipotesis ketiga yang dirumuskan penelitian ini dinyatakan diterima.

\section{SIMPULAN}

Simpulan yang dapat ditarik berdasarkan hasil dan pembahasan yang sudah dijelaskan sebelumnya yaitu intensitas aktiva tetap berpengaruh negatif pada tax avoidance. Hal ini berarti bahwa semakin tinggi intensitas aktiva tetap perusahaan maka semakin rendah tindakan tax avoidance yang ada di dalam perusahaan. Variabel kompensasi eksekutif berpengaruh positif pada tax avoidance. Hal ini berarti bahwa semakin besar kompensasi eksekutif yang diberikan kepada dewan direksi dan komisaris suatu perusahaan maka semakin besar pula tindakan tax avoidance yang dilakukan perusahaan. Variabel kepemilikan institusional berpengaruh negatif pada tax avoidance. Hal ini berarti bahwa kepemilikan 
institusional suatu perusahaan semakin besar maka semakin rendah tax avoidance yang ada di dalam perusahaan.

Peneliti menyarankan kepada pihak regulator agar dapat membuat serta mengevaluasi kembali regulasi dan kebijakan di bidang pajak sehingga meningkatkan pengawasan untuk meminimalisir tindakan tax avoidance. Peneliti menyarankan kepada emiten untuk menghindari tax avoidance karena akan merugikan perusahaan dan dapat mendapat sanksi yang dapat mengakibatkan menurunnya reputasi perusahaan. Bagi peneliti selanjutnya disarankan untuk menambah atau mempertimbangkan kemungkinan variabel lain yang dapat memengaruhi tax avoidance serta menggunakan perusahaan sektor lainnya.

\section{REFERENSI}

Amelia, V. (2014). Pengaruh Ukuran Perusahaan, Leverage, Profitabilitas, Intensitas Aset Tetap, Intensitas Persediaan Dan Komisaris Independen Terhadap Effective Tax Rate

Aprilia, Majidah, \& Asalam. (2020). Pengaruh Intensitas Aset Tetap, Karakter Eksekutif, Koneksi Politik Dan Leverage Terhadap Tax Avoidance. Jurnal Ilmiah Akuntansi Dan Finansial Indonesia, 3.

Armstrong, C. (2012). The Incentives for Tax Planning. Journal of Accounting and Economics, 53.

Asri \& Suardana (2016). Pengaruh Proporsi Komisaris Independen, Komite Audit, Preferensi Risiko Eksekutif Dan Ukuran Perusahaan Pada Penghindaran Pajak. E-Jurnal Akuntansi Universitas Udayana, 16.

Budiman, J., \& Setiyono. (2012). Pengaruh Karakter Eksekutif terhadap Penghindaran Pajak (Tax Avoidance). Proceeding Simposium Nasional Akuntansi XV Banjaemasin.

Chen, S. (2010). Are Family Firms More Aggressive Than Non-Family Firms? Journal Of Financial Economics.

Derashid, C., \& Zhang, H. (2003). Effective Tax Rates And The Industrial Policy Hypothesis: Evidence From Malaysia. Nal Accounting, Auditing And Taxation, 12(1), 45-62.

Dewi, G. A. P., \& Sari, M. M. (2015). Pengaruh Intensif Eksekutif, Corporate Risk dan Corporate Governance pada Tax Avoidance. E-Jurnal Akuntansi Universitas Udayana, 13.

Dharma, I. M. S., \& Ardiana, P. A. (2016). Pengaruh Leverage, Intensitas Aset Tetap, Ukuran Perusahaan, dan Koneksi Politik Terhadap Tax Avoidance. E-Jurnal Akuntansi Universitas Udayana, 15.

Dowling. (2013). Organizational Legitimacy Social Values and Organizational Behavior Between the Organizations Seek to Establish Congruence. 18.

Dwiyanti, \& Jati. (2019). Pengaruh Profitabilitas, Capital Intensity, dan Inventory Intensity pada Penghindaran Pajak. E-Jurnal Akuntansi.

Dyreng, S. D., Hanlon, M., \& Maydew, E. L. (2008). Long-Run Corporate Tax Avoidance. Accounting Review, 83 (1), 61-82. https://doi.org/10.2308/accr.2008.83.1.61

Eisenhardt, Kathleen M.. (1989). Agency Theory: An Assessment and Review. The Academy of Management Review 1, 14, 57-74. 
Jama', Ahmad Kamal., \& Harnovinsah. (2018). Pengaruh Faktor Keuangan dan Intensitas Aset Tetap terhadap Keputusan Pelaporan Keuangan dan Pajak.Jurnal Tekun, 8(1): 15-33.

Jamaludin, Ali. (2020). Pengaruh Profitabilitas (ROA), Leverage (LTDER) dan Intensitas Aktiva Tetap terhadap Penghindaran pajak (Tax Avoidance).Jurnal Ekonomi dan Bisnis, Vol 7, No 1.2654-5837.

Jamei, R. (2017). Tax Avoidance dan Corporate Governance Mechanisms: Evidence From Tehran Stock Exchange. International Journal Of Economics And Financial Issues.

Jensen, M. C., \& Meckling, W. H. (1976). Theory of The Firm Manajerial Behaviour, Ageny Cost and Ownership Structure. Journal of Financial Economics, 3.

Jihene, Ferchichi \& Dabboussi Moez. (2019). The Moderating Effect of Audit Quality on CEO Compensation and Tax Avoidance: Evidence from Tunisian Context. International Journal of Economics and Financial Issues. Vol. 9 No. 1, 131-139 ISSN: 2146-4138.

Khan, Mozaffar N., Suraj Srinivasan, \& Liang Tan (2016). Institutional Ownership and Corporate Tax Avoidance: New Evidence. Accounting Review Volume 92, Issue 2

Khurana, I, K., \& Moser, W. J. (2011). Institutional Ownership and Tax Aggressiveness. https://doi.org/10.2139/ssrn.1464106

Lestari, G. A. W., \& Dwija Putri, I. G. A. M. A. (2017). Pengaruh Corporate Governance, Koneksi Politik, Dan Leverage Terhadap Penghindaran Pajak. E-Jurnal Akuntansi Universitas Udayana, 18.

Maharani, \& Suardana. (2014). Pengaruh Corporate Governance, Profitabilitas Dan Karakteristik Eksekutif Pada Tax Avoidance Perusahaan Manufaktur. E-Jurnal Akuntansi Universitas Udayana, 9, 525-539.

Mahulae, E. E., Pratomo, D., \& Nurbaiti, A. (2016). Pengaruh Kepemilikan Institusional, Kepemilikan Manajerial, dan Komite Audit terhadap Tax Avoidance. Akuntansi Fakultas Ekonomi Dan Bisnis Universitas Telkom, 3(2), 1626-1633. https://doi.org/10.4234/jjoffamilysociology.28.250

Mulyani, Darminto, \& Endang. (2014). Pengaruh Karakteristik Perusahaan, Koneksi Politik dan Reformasi Perpajakan terhadap Penghindaran Pajak. Jurnal Mahasiswa Perpajakan, 2, 1-47.

Nariastiti, N. W., \& Ratnadi, N. M. D. (2014). Pengaruh Asimetri Informasi, Corporate Governance dan Ukuran Perusahaan pada Manajemen Laba. EJurnal Akuntansi Universitas Udayana, 9.

Ngadiman, \& Puspitasari. (2014). Pengaruh Leverage, Kepemilikan Institusional, dan Ukuran Perusahaan terhadap Penghindaran Pajak (Tax Avoidance) pada Perusahaan Sektor Manufaktur yang Terdaftar di Bursa Efek Indonesia 2010-2012. Jurnal Akuntansi, 18.

Noor, R. M. F., \& Matsuki, N. A. (2010). Corporate Tax Planning: A Study On Corporate Effective Tax Rates Of Malaysian Listed Companies. International Journal Of Trade, Economics And Finance, I(2), 189-193.

Nugraha \& Mulyani. (2019). Peran Leverage Sebagai Pemediasi Pengaruh Karakter Eksekutif, Kompensasi Eksekutif, Capital Intensity, Dan Sales Growth Terhadap Tax AvoidanceJurnal Akuntansi Trisakti. Vol. 6 No. 2, 301-324 ISSN : 2339-0832. $h t t p: / / d x . d o i . o r g / 10.25105 / j a t . v 6 i 2.5575$ 
Noviyani, E., \& Muid, D. (2019). Pengaruh Return On Assets, Leverage, Ukuran Perusahaan, Intensitas Aset Tetap dan kepemilikan Institusional Terhadap Penghindaran Pajak. Diponegoro Journal Of Accpunting, 8(3).

Phillips, John D. (2003). Corporate Tax-Planning Effectiveness: The Role of Compensation-Based Incentives. The Accounting Review 78 No. 3.

Pitaloka, \& Merkusiwati. (2019). Pengaruh Profitabilitas, Leverage, Komite Audit, dan Karakter Eksekutif Terhadap Tax Avoidance. E-Jurnal Akuntansi Universitas Udayana, 27. https://doi.org/10.24843/EJA.2019.v27.i02.p14

Praditasari, N. K. A., \& Setiawan, P. E. (2017). Pengaruh Good Corporate Governance, Ukuran Perusahaan, Leverage Dan Profitabilitas Pada Tax Avoidance. E-Jurnal Akuntansi Universitas Udayana, 19(2), 1229-1258.

Resmi. (2012). Perpajakan Teori dan Kasus. Salemba Empat.

Riskatari \& Jati. (2020). Pengaruh Ukuran Perusahaan, Leverage, Profitabilitas Dan Corporate Social Responsibility Terhadap Penghindaran Pajak. EJurnal Akuntansi, 30.

Sabli, Nurshamimi dan Noor, Rohaya. (2012). Tax Planning and Corporate Governance. 3 rd International Conference on Business and Economic Research Proceeding. ISBN: 978-967-5705-05-2.

Wirawan, I. M. D. S. \& Wirakusuma, M. D. (2018). Kepemilikan Manajerial Sebagai Pemoderasi Pengaruh Kompensasi Manajemen dan Karakteristik Eksekutif Terhadap Risiko pada Tax Avoidance. Jurnal Buletin Studi Ekonomi. Vol. 23 No. 1.

Xynas, L. (2011). Tax Planning, Avoidance and Evasion in Australia 1970-2010: The Regulatory Responses and Taxpayer Compliance. Revenue Law Journal, 20. 